\title{
$\mathbb{I}$

\section{Upaya Meningkatkan Keterampilan Menulis Puisi Keindahan Alam Melalui Media Alam Sekitar Pada Siswa Kelas V SDN 05 Riwang Kabupaten Luwu}

\author{
Ratna \\ Institut Agama Islam Negeri Palopo \\ ratnaphay9@gmail.coml
}

\begin{abstract}
This study aims to determine the improvement of poetry writing skills by using natural media around fifth grade students at SDN 05 Riwang, Larompong District, Luwu District. This research is a classroom action research consisting of two cycles with the stages of Planning, Implementation, Observation and Reflection. The subject of this research is the fifthgrade students in the odd semester of 2017/2018 school year with 20 students. Sources of data in this study are primary data and secondary data. Data collection tests were carried out using interviews, observations, and tests of processing techniques and data analysis used, namely quantitative data analysis and qualitative data analysis. The results of the study showed that the use of natural media around the poetry of natural beauty has increased each cycle. which carried out as many as two cycles showed that the completeness of student learning outcomes, Indonesian subjects poetry material of natural beauty has increased, the average value in cycle I was 75 with completeness $80 \%$, and increased in cycle II which is 95 with $100 \%$ completeness, It can be concluded that, using natural media around will help a teacher in carrying out learning activities and students will be easier to understand, so that students at SDN 05 Riwang, Larompong District, Luwu Regency, can improve learning outcomes.
\end{abstract}

Keywords: Poetry Writing Skills, Natural Media around 


\section{A. Pendahuluan}

Mengajar adalah suatu upaya yang dilakukan guru agar siswa lebih aktif dalam proses pembelajaran dan belajar adalah upaya seorang siswa untuk merubah kepribadian atau prilaku dalam dirinya agar lebih baik lagi ( Purwanto, 2014: 57). Belajar adalah suatu kegiatan yang dilakukan untuk memperoleh sejumlah ilmu pengetahuan. Dalam belajar, kita tidak bisa melepaskan diri dari beberapa hal yang dapat mengantarkan kita berhasil dalam belajar.

Pada hakikatnya belajar adalah proses interaksi yang yang dilakukan pada setiap individu siswa terhadap semua situasi ada disekitarnya. Belajar dapat dipandang sebagai proses yang diarahkan kepada pencapaian tujuan dan proses perbuatan melalui berbagai pengalaman yang diciptakan guru (Rusman, 2013: 5). Melalui pendidikan dengan mengenalkan huruf, kata, kalimat, dan susunan kalimat manusia dapat menyampaikan pesan-pesan, informasi keilmuan yang menjadikan mereka mengetahui, mengerti, memahami, dan memiliki wawasan yang luas (Mujamil Qomar,2012: 20). Sedangkan pembelajaran merupakan istilah baru yang digunakan untuk menunjukkan kegiatan guru dan peserta didik. Pembelajaran memiliki andil dalam proses pembudayaan dan pemberdayaan peserta didik. Dalam pasal 4 ayat (3) undang-undang nomor 20 tahun 2003 disebutkan bahwa "pendidikan diselenggarakan sebagai suatu proses pembudayaan dan pemberdayaan peserta didik yang berlangsung sepanjang hayat" (Syamsu S, 2015: 20).

Pembelajaran bahasa Indonesia merupakan pelajaran yang bisa diajarkan diluar kelas Karena tidak membutuhkan konsentrasi penuh. Namun meskipun diajarkan di luar kelas, seorang guru harus tetap mampu mencapai tujuan belajar bahasa Indonesia, yaitu membuat siswa mampu menggunakan Bahasa Indonesia sebagai alat komunikasi yang akan menunjukan anak untuk memiliki pengetahuan dan keterampilan berbahasa dan memudahkan mereka untuk berkomunikasi dengan orang-orang disekitarnya ( Adelia Vera, 2012: 66 ). Pembelajaran bahasa Indonesia sekolah dasar diarahkan untuk meningkatkan kemampuan peserta didik dalam berkomunikasi dengan baik, baik secara lisan maupun tulisan. Dalam bahasa Indonesia harus kita harus tau apa itu Gaya bahasa adalah kemampuan seseorang dalam mengumpamakan objek dengan gaya bahasa tertentu (natia, 2008: 4). Sejalan dengan hal tersebut (Sukirman dan Edhy, 2010: 7) berpendapat bahwa dengan aspek berbicara dan aspek menulis merupakan aspek berbahasa yang bertujuan mengungkapkan isi hati, pendapat dan gagasan seseorang kepada orang lain. Hal ini terluput dengan karya satra.

Karya sastra adalah fenomena unik ia juga fenomena organik di dalamnya penuh serangkaian makna dan fungsi. Makna dan fungsi ini sering kabur dan tak jelas. Oleh karena, karya sastra memang syarat dengan imajinasi. Itulah sebabnya peneliti sastra tugas untuk mengungkap kekaburan itu menjadi jelas (Suwardi endaswara, 2011: 7 ). Dalam menuangkan karya ataukah imajinasi pikiran maka kita bisa menuangkan dengan bentuk tulisan. Menulis merupakan kegiatan yang paling sering dilakukan oleh setiap orang. Menulis membutuhkan keterampilan khusus yang harus dipelajari dan senantiasa dilatih. Menulis memerlukan keterampilan tambahan bahkan motivasi tambahan pula, hal ini dikarenakan menulis bukan bakat karena tidak semua orang mampu untuk 
menulis. Menulis bukan sekadar coretan tinta yang dituangkan dalam tinta yang dituangkan dalam buku, namun harus mempunyai makna dan informasi yang akan disampaikan maka dari itu kita memerlukan adanya media pembelajaran (Ahmad Susanto, 2013: 246). Kesalahan dalam menulis dapat menyebabkan perubahan makna kalimat tersebut sehingga terjadi kesalahan dalam penafsiran kalimat tersebut (Rustan, 2016).

Media pembelajaran adalah alat yang dapat membantu proses pembelajaran dan berfungsi untuk memperjelas penyampaian guru kepada siswa pada saat proses pembelajaran berlangsung sehingga dapat mencapai tujuan pembelajaran dengan baik (Kustandi dan Sutjipti, 2011: 9). Media lingkungan (alam sekitar) merupakan media yang murah meriah, namun dapat digunakan untuk hasil yang maksimal. Media ini memiliki banyak kelebihan jika dibandingkan dengan media-media lain, salah satunya dapat menghilangkan kejenuhan siswa karena terus belajar di ruangan kelas. Media pembelajaran adalah segalah sesuatu yang dapat digunakan untuk menyalurkan pesan dan perangsang terjadinya prosesbelajar pada si pelajar (zainal aqib, 2013: 49-50). Alasan kenapa dibutuhkannya sebua media pembelajaran dalam proses pembelajaran karena guru harus berusaha memberikan materi yang diajarkan kepada siswa mudah diterimah atau mudah dipahami siswa, dan juga tidak membebankan siswa dalam segi materi ( Subana, : 290-291).

Berdasarkan hasil observasi yang dilakukan penulis pada SDN 05 Riwang Kecamatan Larompong Kabupaten Luwu yaitu: siswa mengalami kesulitan menuangkan pikiran dan perasaannya dalam bentuk puisi. Kesulitan yang dihadapi siswa itu ditandai dengan beberapa hal seperti siswa kesulitan menemukan ide, menemukan kata pertama dalam puisinya, mengembangkan ide menjadi puisi karena minimnya penguasaan kosa kata, karena tidak terbiasa mengemukakan perasaan, pemikiran, dan imajinasinya ke dalam puisi. Guru hanya mengajar teori tentang puisi dan tidak pernah mengadakan praktik menulis puisi.

Jika ada materi tentang membaca puisi, guru tidak pernah menuntut siswanya untuk membacakan puisi karya mereka sendiri, selain itu sebagian besar dari mereka belum bisa menggunakan bahasa baku yang benar, melainkan sering menggunakan bahasa daerah dari daerah masing-masing. Para siswa cukup mencari dari buku ataupun internet, lalu membacakannya di depan kelas. Hal itu membuat siswa semakin tidak tau. Media ini sangat murah namun dapat dipergunakan secara sangat efektif untuk pembelajaran. Selain itu, media alam sekitar juga dapat menghilangkan kebosanan siswa. Belajar selama ini selalu di ruang kelas, akan tetapi dengan media alam sekitar siswa dapat diajak ke luar ruangan pada saat pembelajaran berlangsung. Hal ini akan menarik perhatian siswa, sehingga tujuan pembelajaran dapat tercapai. Setiap individu, dapat mengembangkan kepribadiannya melalui belajar.

Dan juga tidak lepas dari model pembelajaran. Model merupakan sesuatu yang dapat memberi gambaran tentang adanya pola berpikir, keseluruha konsep yang saling berkaitan biasanya dapat bergambar dalam sebuah model ( benny A.pribadi 2009 : 86). Model pembelajaran ialah pola yang digunakan sebagai pedoman dalam merencanakan pembelajaran di kelas maupun tutorial. Menurut 
Arends, model pembelajaran mengacu pada pendekatan yang akan digunakan, termasuk didalamnya tujuan-tujuan pembelajaran, tahap-tahap dalam kegiatan pembelajaran, lingkungan pembelajaran dan pengelolaan kelas. Model pembelajaran dapat didefenisikan sebagai kerangka konseptual yang melukiskan prosedur sistematis dalam mengorganisasikan pengalaman belajar untuk mencapai tujuan belajar (Agus Suprijono, 2009: 46). Hasil belajar adalah kemampuan-kemampuan yang dimiliki siswa setelah ia mendapatkan pengalaman belajarnya (Nana Sudjana, 2011: 22). Hasil belajar memiliki beberapa ranah atau kategori dan secara umum merujuk kepada aspek pengetahuan, sikap, dan keterampilan (Hamzah B Uno, 2012: 213). Hasil belajar seringkali digunakan sebagaiukuran untuk mengetahui seberapa jauh seseorang menguasai bahan yang sudah diajarkan (Purwanto, 2014: 44). Hasil belajar pencapaian bentuk perubahan perilaku yang cenderung menetap dari ranah kognitif, afektif, dan psikomotorik dan proses belajar yang dilakukan dalam waktu tertntu (Asep Jihad \& Abdul Haris, 2013: 14.jadi hasil belajar siswa dipengarui dengan adanya media yang digunakan dalam proses pembelajaran.

Setelah melihat keterampilan menulis puisi siswa yang minim disebabkan dengan kurangnya media yang diberikan oleh pendidik maka dari itu peneliti berupaya mengambil tindakan dengan memberikan siswa media alam sekitar agar siswa mampu dengan mudah mendapatkan kata yang akan dituangkan dalam puisinya agar dapat meningkatkan keterampilan siswa.

\section{B. Research Methodology}

Penelitian ini menggunakan pendekatan kualitatif dan pendekatan kuantitatif, Jenis penelitian ini adalah penelitian tindakan kelas. Penelitian ini dirancang untuk meningkatkan atau mampu memecahkan masalah-masalah yang terjadi di kelas maupun di luar kelas dengan adanya partisipasi dan kolaborasi antara peneliti dengan anggota kelompok sasaran dalam hal ini adalah guru dan siswa kelas V SDN 05 Riwang Kecamatan Larompong Kabupaten Luwu yang terdiri dari dua siklus, sumber data yang digunakan dalam penelitian ini yaitu dengan menggunakan data primer dan data sekunder, ada pun teknik pengumpulan datanya yaitu tes,wawancara dan observasi. penelitian ini menggunakan teknik analisis data secara kuantitatif dan kualitatif, Data kualitatif dianalisis dengan teknik analisis deskriptif kualitatif, yaitu teknik pengolahan data dengan cara mendeskripsikan hasil data kualitatif yang meliputi hasil observasi, catatan lapangan dan hasil wawancara. Sedangkan data kuantitatif dianalisis dengan menggunakan statistik deskriptif dengan penyimpulan lebih mendasarkan dari pada nilai rata-rata dan simpangan baku amatan atau persentase amatan Siswa dikatakan tuntas belajar secara individual jika siswa tersebut telah memperoleh nilai KKM (Kreteria ketuntasan minimum).

Penelitian ini dilaksanakan dalam beberapa siklus, siklus satu dilakukan dua kali tatap muka dalam pembelajaran dan siklus dua juga dilakukan dua kali tatap muka dalam pembelajaran, Adapun masing-masing siklus terdiri dari 4 tahapan, yaitu; perencanaan, pelaksanaan, pengamatan, refleksi, hal ini sesuai dengan model penelitian yang peneliti pilih, yaitu dengan menggunakan model Kemmis dan Taggart. 


\section{Hasil Penelitian}

Media pembelajaran sangat membantu dalam peningkatan hasil belajar siswa. Dengan menggunakan alat peraga merupakan salah satu dari media pendidikan untuk membantu proses belajar mengajar agar proses komunikasi dapat berhasil dengan baik dan efektif.penggunaan media aam sekita sangat membantu memudahkan prose pembelajaran apalagi diterapkan di SD, siswa yang belum tau dapat menemukan ide yang dapat dituangkan dalam puisinya sehingga tecipta tulisan yang indah dan terkandung makna yang baik. Dengan menggunakan media alam proses belajar mengajar dari siklus 1 ke siklus II meningkat.

Setelah peneliti menerapkan media alam sekitar pada materi puisi keindahan alam terhadap siswa kelas V SDN 05 Riwang Kecamatan Larompong Kabupaten Luwu, dapat diketahui bahwa dengan menggunakan media alam sekitar peningkatan keterampilan menulis puisi setiap siklusnya mengalami peningkatan. Hal tersebut dapat diketahui berdasarkan hasil tes yan g dilakukan pada setiap akhir pertemuan mulai dari prasiklus, siklus I dan siklus II Peningkatan digambarkan dalam diagram sebagai berikut.

\section{Nilai rata-rata hasil belajar siswa pada pembelajaran Bahasa Indonesia dengan materi puisi keindahan alam melalui media alam sekitar}

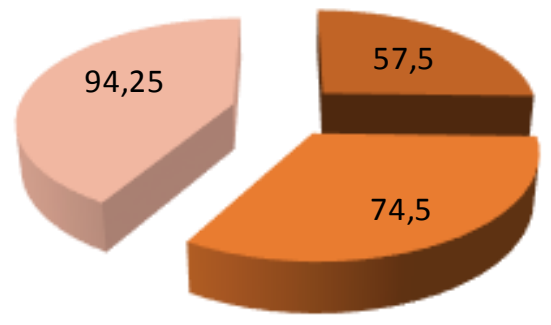

Berdasarkan diagram di atas tes awal di prasiklus guru masih belum menerapkan media pembelajaran dengan baik, seh ingga membuat siswa kurang berminat dengan pembelajaran menulis puisi. setelah dilakukan implementasi dengan menggunakan media alam sekitar dalam kegiatan menulis puisi siswa kelas V di SDN 05 Riwang dapat termotivasi menulis puisi dengan baik. Hal tersebut terlihat pada peningkatan kualitas proses pemeblajaran menulis puisi siswa, sehinggasiswa lebih antusias mengikuti pembelajaran dikelas.

Peningkatan ini merupakan peningktan nilai rata-rata tes menulis puisi siswa dari tahap prasiklus hingga tes akhir pada sisklus II yang mengalami peningkatan. Peningkatan tersebut juga terjadi pada setiap aspek penilaian meliputi aspek kesesuaian tema dengan isi, aspek pencitraan, aspek diksi, aspek pemajasan, aspek amanat. Nilai rata-rata pada prasiklus adalah 57,5, dan nilai rata-rata tersebut meningkat pada siklus I menjadi 74,5 kemudian meningkat lagi pada siklus II sebesar 94,25. Jadi dengan menggunakan media alam dalam 
pembelajaran bahasa pokok bahasan Indonesia puisi dapat meningkatkan keterampilan menulis puisi.

\section{Pembahasan}

Proses pembelajaran dengan menggunakan media alam sekitar dapat meningkatkan keterampilan menululis puisi siswa. Penelitian ini dilakukan sebagai upaya meningkatkan keterampilan menulis puisi Keindahan alam melalui media alam sekitar. Dengan cara siswa dibawa keluar kelas untuk diunjukan media yang akan mereka jadikan sebagai puisi, guru menugaskan siswa untuk mencari kata-kata yang akan dituangkan dalam puisi tersebut. dalam hal ini meia pembelajaran dapat memudahkan uru dalam proses pembelajaran.

Pada siklus I, proses yang dilakukan dari perencanaan hingga refleksi hingga refleksi belum mendapatkan hasil yang diterapkan beberapa siswa masih kesulitan menemukan diksi yang tepat, citraan dan majas. Sebagian besar siswa belum memunculkan pencitraan dan majas yang tepat. Berdasarkan hasil pelaksanaan siklus I tersebut, dapat diketahui bahwamasih perlu dilaksanakan perbaikan pada siklus II. terkait dengan materi menulis puisi, guru melakukan perbaikan agar siswa menguasai materi yang mampu menerapkan dalam kegiatan menulis puisi, sehingga mampu menghasilkan puisi yang lebih baik.

Pada siklus II guru menjelaskan kembali unsure-unsur pembangun puisi berdasarkan contoh konkrit yaitu melalu media alam sekitar. Akn tetapi, pada siklus II ini, guru lebih menekankan pada aspek-aspek yang kurang selama siklus I, yaitu pada aspek pemilihan diksi, citraan dan majas, dalam siklus II ini, guru mengajak siswa untuk keluar kelas melihat media yang telah disediakan, berbeda dari siklus I.siswa diminta untuk memperhatikan memunculkan tema, citraan, diksi, majas, dan amanat pada media tersebut.pada siklus II ini guru berupaya menciptakan suasan yang lebih santai dan akrab. pembelajaran menulis puisi yang menyenangkan membuat siswa senang dan menikmati jalannya proses pembelajaran. Suasana santai dalam proses pembelajaran dapat menghilangkan stres, kelelahan, meningkatkan kepercayaan diri serta minat belajar siswa (Rustan \& Bahru, 2018).

Dengan menggunakan media alam sekitar dapat meningkatkan keterampilan menulis puisi siswa kelas V di SDN 05 Riwang. Hasil penelitian yang telah dilakukan sebanyak dua siklus menunjukan bahwa media alam sekitar mampu meningkatkan hasil belajar siswa. Keberhasilan penelitian ini ditunjukkan melalui peningkatan hasil belajar siswa yang menjadi subjek penelitian. Pada pelaksanaan prasiklus rata-rata nilai tes awal siswa hanya mencapai 57,5. Berdasarkan persentase ketuntasan hasil belajar siswa kelas V SDN 05 Riwang setelah menggunakan media pembelajaran yaitu media alam sekitar pada materi puisi keindahan alam, dapat dilihat bahwa banyaknya siswa yang tuntas pada siklus I sebanyak 11 siswa dan banyaknya siswa yang tidak tuntas sebanyak 9 siswa, sedangkan siswa yang tuntas pada siklus II sebanyak 20 siswa.

Setelah pelaksanaan tindakan pada siklus II, terjadi peningkatan kualitas proses belajar mengajar pada mata pelajaran Bahasa Indonesia materi puisi 
keindahan alam. Hal ini disebabkan penggunaan media yang disesuaikan dengan materi yang di ajarkan.

\section{E. Penutup}

Setelah melakukan penelitian selama kurang lebih 2 bulan dengan menerapkan media alam sekitar dengan materi puisi keindahan alam, menggunakan 2 siklus maka dapat ditarik kesimpulan bahwa dengan membawa siswa keluar kelas siswa lebih bermotivasi mengkuti proses pembelajaran dan lebih cepat diambil perhatiannya ketimbang didalam kelas. Tes hasil belajar siswa kelas V SDN 05 Riwang Kecamatan Larompong Kabupaten Luwu yang dilakukan sebanyak dua siklus menunjukkan bahwa ketuntasan hasil belajar siswa materi puisi keindahan alam mengalami peningkatan. Nilai rata-rata pada Prasiklus adalah 57,5 dengan ketuntasan 10\%, kemudian mengalami peningkatan pada siklus I adalah 75 dengan ketuntasan $80 \%$ dan mengalami peningkatan pada siklus II yaitu 95 dengan ketuntasan 100\%. Penggunaan media yang sesuai dengan materi pelajaran akan membantu seorang guru dalam melaksanakan kegiatan pembelajaran dan siswa akan lebih mudah mengerti tentang apa yang disampaikan pada saat proses pembelajaran.

\section{DAFTAR PUSTAKA}

Arikunto, Suharsimi, dkk, 2011 Penelitian Tindakan Kelas. Cet. X; Jakarta: PT Bumi Aksara.

Aqib, Zainal. 2013. Model-Model, Media dan Strategi Pembelajaran Kontekstual (Inovatif), Bandung: Yrama Widya

Budiningsih, asri. 2008. Belajar dan pembelajaran. Cet, 1; Jakarta: Rineka Cipta, Endaswara, Suwardi. 2011. Metodologi Penelitian Sastra, Yogyakarta: CAPS Kav. Madukismo,

Haris Abdul dan Jihad Asep. 2013. Evaluasi Pembelajaran. Yogyakarta: Multi Pressindo

Natia. 2008. Apresiasi Sastra Indonesia. Surabaya: Bintang.

Nurdjan, S., dan Rustan, E. 2010. Kunci Sukses Berbahasa Indonesia. (Palopo: Lembaga Penerbitan STAIN (LPS).

Muliawan, Jasa Ungguh. 2010. Penelitian Tindakan Kelas. Cet, 1: Yogyakarta: Gava Media,

Qomar, Mujamil 2012. Kesadaran Pendidikan. Jogjakarta: Ar-Ruzz Media Pribadi A Benny. 2009. Model Desain Pembelajaran. Jakarta Dian Rakyat Purwanto. 2014. Evaluasi hasil belajar Cet, VI; Yogyakarta: Pustaka Pelajar. Rusma, dkk. 2013. Pembelajaran Berbasis Teknologi Informasi dan Komunikasi Mengembangkan Profesionalitas Guru. Cet,2013 Jakarta: Pt Raja Grafindo Persada,

Rustan, E. (2016). Analisis Penggunaan Bahasa Indonesia Laras Hukum Pada Putusan Perkara Ekonomi Syariah Pengadilan Agama Makassar. AlAmwal: Journal of Islamic Economic Law, 1(2), 166-176. https://doi.org/10.24256/alw.v1i2.278 
Rustan, E., \& Bahru, M. S. (2018). Penguatan Self Confidence dalam Pembelajaran Matematika melalui Metode Suggestopedia. Al-Khwarizmi: Jurnal Pendidikan Matematika Dan Ilmu Pengetahuan Alam, 6(1), 1-14.

Syamsu S. 2015. Strategi Pembelajaran Meningkatkan Kompetensi Guru, Cet, 1; Makassar: Aksara Timur

Suryosubroto. 1997. Proses Belajar Mengajar di Sekolah. Cet, I: Jakarta: Rineka Cipta

Sutjipto, Kustandi. 2011. Media Pembelajaran Manual dan digital. Jakarta: Ghalia Indonesia.

Sudjana Nana. 2011. Dasar-Dasar Proses Belajar Mengajar. Bandung: Sinar Baru Algensindo

Subana. Strategi Belajar Mengajar Bahasa Indonesia. Pustaka Setia

Sanjaya wina. 2009. Penelitian Tindakan Kelas, Cet 1 Jakarta: Gava Media

Susanto, Ahmad. 2013. Teori Belajar Dan Pembelajaran di Sekolah Dasar. Jakarta: Prenada Media Group

Suprijono Agus. 2009. Cooperative Learning. Cileban Timur: Pustaka Pelajar,

Soepomo. 1993. Dasar-dasar Interaksi Belajar Mengajar.Cet I Surabaya: Usaha Nasional

Taniredja Tukiran, dkk. 2013. Penelitian Tindakan Kelas, Bandung: Alfabeta, Cet. Lima

Uno B. Hamzah. 2012. Model Pembelajaran. Jakarta: Remaja Rosda karya

Vera, Ade Lia. 2012. Metode Mengajar Anak di Luar Kelas, Cet 1 Jogjakarta: Diva Press

Zainuddin. 1992. Materi Pokok Bahasa dan Sastra Indonesia. Jakarta: Rineka Cipta 